\title{
Chemical composition and antibacterial activity of essential oil of Tetraclinis articulata (Vahl) Masters branches of eastern Morocco
}

\author{
Fatima Zahra Sadiki ${ }^{*}$ (D), Mostafa El Idrissi ${ }^{1}$, Mohammed Sbiti ${ }^{2}$, Adrae Lemrhari ${ }^{3}$, Adriana Trifan ${ }^{4}$, Oana Cioanca ${ }^{4}$, \\ Paula Alexandra Postu ${ }^{5}$ and Lucian Hritcu ${ }^{5}$
}

\begin{abstract}
Background: Some pathogenic microbial species are becoming less sensitive to antibiotics and developing resistance multiples. The use of essential oils is a serious substitute for treatment with antibiotics in infectious diseases. The present study aims to investigate the chemical composition and to evaluate the antibacterial activity of the essential oil of branches of Tetraclinis articulata (Vahl) Masters (Cupressaceae).

Methods: The extraction of the essential oil was realized by hydrodistillation, and the analysis was carried out by gas chromatography coupled with mass spectroscopy (GC-MS/FID). The antibacterial test was carried out using two different methods: the disc diffusion method and the macrodilution method which aims to determine the minimum inhibitory concentration (MIC).

Results: The yield of essential oil was $0.84 \%$. Chromatographic analysis revealed that the major constituents were a-pinene (38.75\%), limonene (13.24\%), bornyl acetate (8.78\%) and camphor (7.68\%). The results of the antibacterial activity show that the essential oil exerts a powerful effect to inhibit some strains tested.
\end{abstract}

Conclusions: The antibacterial activity demonstrated in this study could justify the traditional uses of this plant and could contribute to value its potential in order to develop new bioactive compounds.

Keywords: Tetraclinis articulata (Vahl) Masters, Antibacterial activity, MIC, Camphor

\section{Introduction}

In the field of anti-infectives, the discovery of new substances has always been the goal of Human, since the main cause of death in the past was infectious diseases [1]. When penicillin therapy was first performed, Human thought he had won the battle against pathogenic bacteria. However, with the appearance of penicillin-resistant bacteria, he had the impression of regression, and with the extraction and synthesis of new powerful antibiotics, the fear dispersed. Nevertheless, like any drug, antibiotics are not totally harmless to the body and can cause many side effects [2]. These antibiotics, which have saved lives

\footnotetext{
*Correspondence: fatizahrasad@gmail.com

${ }^{1}$ Laboratory of Molecular Chemistry and Natural Substances, Department of Chemistry, Faculty of Sciences of Meknes, Moulay Ismail University, Bp

11201, Zitoune, Meknes, Morocco

Full list of author information is available at the end of the article
}

and relived the sufferance of millions of people for years to date, are also threatened by the emergence and spread of multi-resistant germs.

In order to overcome the problem of resistance of microorganisms to antibiotics, most of the work is currently oriented towards other antimicrobial agents with a very specific mode of action. Thus, researchers and scientists are trying to find effective and accessible alternatives from natural products extracted from medicinal and aromatic plants, which are known to be endowed with antimicrobial properties [3-11].

Among the aromatic plants, Tetraclinis articulata (Vahl) Mast. Synonyms (Cupressaceae), Barbary thuja synonyms of Callitris quadrivalvis Rich and A. Rich., Thuja articulata Vahl, resinous species belonging to the order Pinales, known in Morocco as the "Araar", is characterized by its resistance to destructive agents and the 
use of its wood in crafts, carpentry and cabinetry. It is endemic in the south western Mediterranean and especially the Maghreb [12]. In Morocco, forests cover about 566.000 ha, and are divided into 6 major biogeographic units at the Rif, oriental, eastern Middle Atlas, valleys of the central plateau and the western plateau, Western Middle Atlas and High Atlas. In traditional medicine, the different parts of the tree, particularly the leaves and branches, are used in the treatment of intestinal and respiratory infections [13].

A research in the scientific literature indicates that there are few reports of studies on the antibacterial properties and chemical composition of essential oil extracted from the branches of the Thuja. In this context, this study was conducted in order to put under scrutiny the chemical composition and to evaluate the antibacterial activity of this essential oil.

\section{Materials and methods}

\section{Plant material and extraction}

The branches of Tetraclinis articulata were harvested in April (2016) in the forest of Tafoughalt-zegzel (Latitude: $34^{\circ} 50^{\prime} 20^{\prime \prime} \mathrm{N}$; Longitude: $\left.2^{\circ} 24^{\prime} 49^{\prime \prime} \mathrm{W}\right)$, region in East of Morocco. The extraction of essential oil was carried out by hydrodistillation in a Clevenger-type apparatus [14]. Three distillations were performed for $3 \mathrm{~h}$. The essential oil was stored at $4{ }^{\circ} \mathrm{C}$ in the dark before proceeding with chromatographic analysis and biological activities.

\section{Chromatographic analysis}

The analysis of the essential oil was performed using Agilent 6890 GC-MS system, equipped with a split/splitless injector. GC-MS conditions were line/detector temperature $250{ }^{\circ} \mathrm{C}$, carrier gas (helium, $1 \mathrm{~mL} / \mathrm{min}$ ), split ratio 100:1, and capillary column DB5MS $(30 \mathrm{~m} \times 0.25 \mathrm{~mm}$; film thickness $0.25 \mu \mathrm{m}$, Agilent, Palo Alto, CA, USA). The temperature program was established to grow with $10{ }^{\circ} \mathrm{C} /$ min up to $280^{\circ} \mathrm{C}$. The injected volume was $0.30 \mu \mathrm{L}$ with a total scan time of $32 \mathrm{~min}$. The GC-FID analysis used an Agilent type 6890 GC connected to a FID detector and all method and analysis parameters were the same as those described above.

\section{Microorganisms studied}

Eight clinical bacteria were chosen for their pathogenicity, and they have been isolated from the various samples (Table 1). Isolation and identification of clinical strains were performed at the microbiology laboratory of Military Hospital Moulay Ismail in Meknes.

\section{Tests for antibacterial activity \\ Determination of the inhibition diameter (solid method)}

The diffusion method from a solid disc was used to demonstrate the antibacterial activity. A bacterial suspension was diluted and adjusted to turbidity equal to that of the McFarland standard $0.5\left(10^{8} \mathrm{CFU} / \mathrm{mL}\right)$. The Mueller-Hinton Agar was poured into Petri dishes $90 \mathrm{~mm}$ in diameter. The agar surface was seeded with the microbial suspension. Paper dishes, of $6 \mathrm{~mm}$ diameter impregnated with $10 \mu \mathrm{L}$ of the essential oil, were deposited on the surface of the agar. The dishes were then incubated at $37{ }^{\circ} \mathrm{C}$ for $24 \mathrm{~h}$. After incubation, an area or clear halo is present around a disc if the essential oil inhibits bacterial growth. All tests were repeated three times.

\section{Broth dilution method (determination of MIC and MBC)}

A cascade dilution was performed in Mueller-Hinton Broth-Tween $80(0.01 \%, \mathrm{v} / \mathrm{v})$, so as to obtain a concentration range between $80 \mu \mathrm{L} / \mathrm{mL}$ and $0.3 \mu \mathrm{L} / \mathrm{mL} .13 \mu \mathrm{L}$ of a bacterial inoculum, equivalent to the standard density of $0.5 \mathrm{McF}$ arland $\left(10^{8} \mathrm{UFC} / \mathrm{mL}\right)$, was deposited in each of the tubes of the range. A control of the bacterial growth, for which $13 \mu \mathrm{L}$ of the standardized inoculum was deposited in MHB-Tween 80 medium $(0.01 \%, \mathrm{v} / \mathrm{v})$, was also carried out. The tubes were incubated at $37{ }^{\circ} \mathrm{C}$ for $24 \mathrm{~h}$. The MIC was determined by the lowest concentration of essential oil giving a growth inhibition.

Table 1 Profile of tested bacteria

\begin{tabular}{|c|c|c|c|c|}
\hline Bacterial strains & Gram & Profile & Sex & Nature of sampling \\
\hline Escherichia coli & Gram-negative bacilli & $\mathrm{ESBL}$ & Male & Cytobacteriological urine exam \\
\hline Klebsiella pneumoniae & Gram-negative bacilli & $\mathrm{ESBL}$ & Male & Urinary catheter \\
\hline Proteus mirabilis & Gram-negative bacilli & Penicillinase High level & Male & Cytobacteriological urine exam \\
\hline Pseudomonas aeruginosa & Gram-negative bacilli & Low level & Female & Coproculture (stool bacteria) \\
\hline Acinetobacter baumannii & Gram-negative bacilli & Multi-resistant & Male & Cytobacteriological urine exam \\
\hline Staphylococcus epidermidis & Gram-positive cocci & Multi-resistant & Male & Urethral \\
\hline Staphylococcus non aureus & Gram-positive cocci & Multi-sensitive & Female & Pus \\
\hline Staphylococcus aureus & Gram-positive cocci & Multi-sensitive & Male & Pus \\
\hline
\end{tabular}


Table 2 Chemical composition of essential oil of Tetraclinis articulata branches

\begin{tabular}{|c|c|c|c|}
\hline Compound & Area & RT & Formula \\
\hline Tricyclene & 0.92 & 7.92 & $\mathrm{C}_{10} \mathrm{H}_{16}$ \\
\hline a-Pinene & 38.75 & 8.24 & $\mathrm{C}_{10} \mathrm{H}_{16}$ \\
\hline Camphene & 1.48 & 8.52 & $\mathrm{C}_{10} \mathrm{H}_{16}$ \\
\hline Sabinene & 0.58 & 8.90 & $\mathrm{C}_{10} \mathrm{H}_{16}$ \\
\hline$\beta$-Pinene & 1.00 & 9.01 & $\mathrm{C}_{10} \mathrm{H}_{16}$ \\
\hline Myrcene & 2.52 & 9.19 & $\mathrm{C}_{10} \mathrm{H}_{16}$ \\
\hline$\Delta$-3-Carene & 0.22 & 9.54 & $\mathrm{C}_{10} \mathrm{H}_{16}$ \\
\hline a-Terpinene & 0.17 & 9.69 & $\mathrm{C}_{10} \mathrm{H}_{16}$ \\
\hline Limonene & 13.24 & 9.99 & $\mathrm{C}_{10} \mathrm{H}_{16}$ \\
\hline a-Ocimene & 0.03 & 10.18 & $\mathrm{C}_{10} \mathrm{H}_{16}$ \\
\hline Terpinolene & 1.17 & 10.89 & $\mathrm{C}_{10} \mathrm{H}_{16}$ \\
\hline (E)-Ocimene & 0.35 & 11.12 & $\mathrm{C}_{10} \mathrm{H}_{16}$ \\
\hline 1,3,8-p-Menthatriene & 0.27 & 11.34 & $\mathrm{C}_{10} \mathrm{H}_{14}$ \\
\hline a-Campholenal & 0.84 & 11.59 & $\mathrm{C}_{10} \mathrm{H}_{16} \mathrm{O}$ \\
\hline p-Mentha-1,3,8-triene & 0.41 & 11.81 & $\mathrm{C}_{10} \mathrm{H}_{14}$ \\
\hline Camphor & 7.68 & 12.03 & $\mathrm{C}_{10} \mathrm{H}_{16} \mathrm{O}$ \\
\hline a-Toluenol & 0.31 & 12.20 & $\mathrm{C}_{7} \mathrm{H}_{8} \mathrm{O}$ \\
\hline Borneol & 2.95 & 12.39 & $\mathrm{C}_{10} \mathrm{H}_{18} \mathrm{O}$ \\
\hline ү-Terpinene & 0.74 & 12.49 & $\mathrm{C}_{10} \mathrm{H}_{16}$ \\
\hline p-Cymenene & 0.49 & 12.58 & $\mathrm{C}_{10} \mathrm{H}_{12}$ \\
\hline Allo-Ocimene & 1.59 & 12.72 & $\mathrm{C}_{10} \mathrm{H}_{16}$ \\
\hline Verbenone & 0.68 & 12.92 & $\mathrm{C}_{10} \mathrm{H}_{14} \mathrm{O}$ \\
\hline Carveol & 0.88 & 13.08 & $\mathrm{C}_{10} \mathrm{H}_{16} \mathrm{O}$ \\
\hline Methyl carvacrol & 0.62 & 13.28 & $\mathrm{C}_{11} \mathrm{H}_{16} \mathrm{O}$ \\
\hline Carvone & 0.45 & 13.43 & $\mathrm{C}_{10} \mathrm{H}_{14} \mathrm{O}$ \\
\hline Bornyl acetate & 8.78 & 14.07 & $\mathrm{C}_{12} \mathrm{H}_{20} \mathrm{O}_{2}$ \\
\hline Carvacrol & 0.94 & 14.28 & $\mathrm{C}_{10} \mathrm{H}_{14} \mathrm{O}$ \\
\hline a-Copaene & 0.97 & 15.37 & $\mathrm{C}_{15} \mathrm{H}_{24}$ \\
\hline$\beta$-Elemene & 0.48 & 15.54 & $\mathrm{C}_{15} \mathrm{H}_{24}$ \\
\hline Aromandendrene & 1.36 & 15.78 & $\mathrm{C}_{15} \mathrm{H}_{24}$ \\
\hline$\beta$-Caryophyllene & 1.11 & 16.03 & $\mathrm{C}_{15} \mathrm{H}_{24}$ \\
\hline Germacrene D & 0.06 & 16.14 & $\mathrm{C}_{15} \mathrm{H}_{24}$ \\
\hline (Z)- $\beta$-Farnesene & 0.15 & 16.39 & $\mathrm{C}_{15} \mathrm{H}_{24}$ \\
\hline a-Humulene & 0.54 & 16.53 & $\mathrm{C}_{15} \mathrm{H}_{24}$ \\
\hline Y-Muurolene & 0.10 & 16.76 & $\mathrm{C}_{15} \mathrm{H}_{24}$ \\
\hline Y-Cadinene & 0.61 & 16.89 & $\mathrm{C}_{15} \mathrm{H}_{24}$ \\
\hline$\beta$-Selinene & 0.19 & 17.01 & $\mathrm{C}_{15} \mathrm{H}_{24}$ \\
\hline a-Selinene & 0.31 & 17.10 & $\mathrm{C}_{15} \mathrm{H}_{24}$ \\
\hline Y-Cadinene & 0.58 & 17.40 & $\mathrm{C}_{15} \mathrm{H}_{24}$ \\
\hline (Z)-a-Farnesene & 0.04 & 18.15 & $\mathrm{C}_{15} \mathrm{H}_{24}$ \\
\hline a-Humulene & 0.26 & 18.84 & $\mathrm{C}_{15} \mathrm{H}_{24}$ \\
\hline Cadina-1(2),4-diene & 1.23 & 19.25 & $\mathrm{C}_{15} \mathrm{H}_{24}$ \\
\hline
\end{tabular}

Italic values indicate the percentage of the major compounds of the essential oil

The minimum bactericidal concentration $(\mathrm{MBC})$ was determined from the MIC. The tubes showed no visible growth with the naked eye after incubation and the control tube, were streaked on MHA. The inoculated dishes were incubated for $24 \mathrm{~h}$ at $37^{\circ} \mathrm{C}$. The $\mathrm{MBC}$ is the lowest concentration that shows no bacterial growth.

\section{Results and discussion \\ The yield of essential oil}

The extraction of essential oil by hydrodistillation from the branches of Tetraclinis articulata enables us to obtain a yield of the order of $0.84 \pm 0.01 \%$. This rate is relatively higher than that reported by Bourkhis et al. (0.41\%) [15]. This shows that certain factors such as the nature of the soil, the climate and quality of the plant material used can influence the secretion of essential oils in a plant.

Identification of chemical composition of essential oil Forty-two compounds were identified, corresponding to $98.89 \%$ of the oil, mainly represented by monoterpenes. The main constituents were $\alpha$-pinene (38.75\%), limonene (13.24\%), bornyl acetate (8.78\%) and camphor (7.68\%). The analysis results are shown in Table 2 and the chromatographic profile is shown in Fig. 1.

Our results are similar to those reported by Bourkhiss et al. [15] who studied the essential oil of branches of Tetraclinis articulata (Vahl) Masters of Khemisset region (Northwester Morocco), and have identified thirty-three compounds representing more than $80 \%$ of the total chemical composition, the main compounds of which were $\alpha$-pinene $(30.22 \%)$, limonene $(22.29 \%)$, widdrol (5.41\%) and bornyl acetate (4.76\%).

Similarly, Buhagiar et al. [16] reported that the essential oil of the terminal branches (woody and non-woody) of Thuja from Malta was characterized, respectively, by $\alpha$-pinene $(31.0 \% ; 46.4 \%)$, followed by bornyl acetate $(19.1 \%$; 7.3\%), camphor $(18.1 \% ; 7.3 \%)$ and limonene $(3.8 \% ; 6.2 \%)$.

Furthermore, Ait Igri et al. [17] have shown a slightly different composition than ours, bornyl acetate (31.10\%), camphor $(20.20 \%)$ and limonene $(7.10 \%)$, which were identified as the major compounds of the essential oil of the branches of Thuja collected in the region of Essaouira (south-west Morocco).

This difference was also seen in the work of TekayaKaraoui et al. [18], where the main components in the essential oil of the terminal branches (non-woody) of Thuja were muurolene (29.0\%) and 4, 6-dimethyl-octane3,5-dione (22.4\%), whereas camphene (43.2\%) and (Z)- $\beta$ ocimene $(11.7 \%)$ were the major compounds in the terminal branches (woody).

These differences in chemical composition of essential oil may be attributed to several factors: seasonal and environmental, soil, geographic area, harvest period, extraction method [19-24]. 


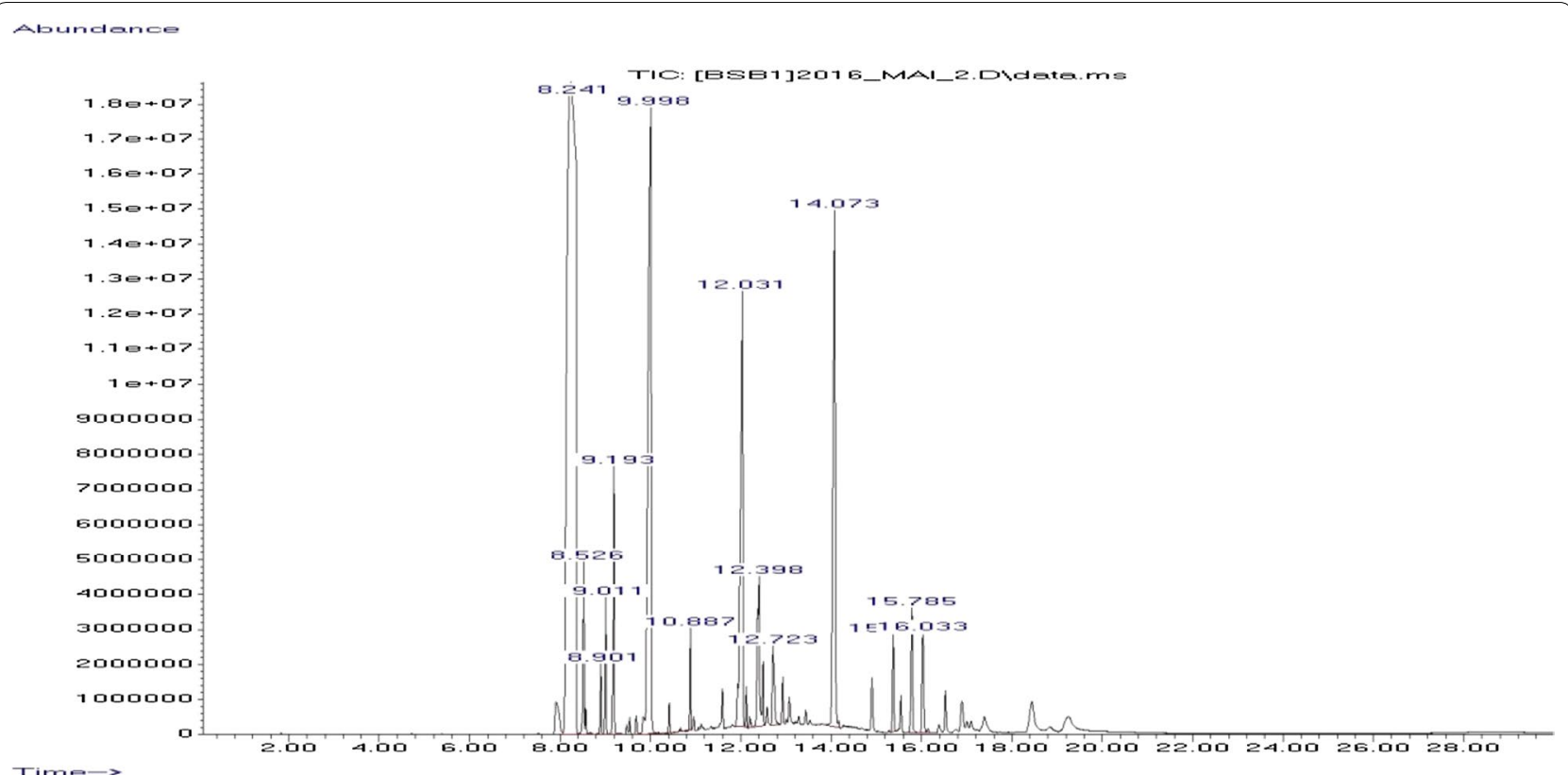

Fig. 1 Chromatographic profile of the essential oil of Tetraclinis articulata branches

Table 3 Antibacterial activity of the essential oil tested by disc diffusion assay

\begin{tabular}{ll}
\hline Bacterial strains & $\begin{array}{l}\text { Zone } \\
\text { of inhibition } \\
\text { (mm) }\end{array}$ \\
\hline Escherichia coli & $19.16 \pm 0.57$ \\
Klebsiella pneumoniae & $6.66 \pm 0.76$ \\
Proteus mirabilis & NA \\
Pseudomonas aeruginosa & NA \\
Acinetobacter baumannii & $17.16 \pm 0.28$ \\
Staphylococcus epidermidis & NA \\
Staphylococcus non aureus & NA \\
Staphylococcus aureus & $9.26 \pm 0.30$
\end{tabular}

NA : no activity found

\section{Antibacterial activity}

According to the results of the aromatogram shown in Table 3, the essential oil exhibited moderate inhibitory power against Escherichia coli and Acinetobacter baumannii, which are antibiotic-resistant strains. The essential oil exhibited low activity against Klebsiella pneumonia and Staphylococcus aureus. The strains Pseudomonas aeruginosa, Proteus mirabilis, Staphylococcus epidermidis, and Staphylococcus non aureus showed no sensitivity for the essential oil of branches of Tetraclinis articulata.

The MIC values are presented in Table 4. The minimum inhibitory concentration for the two bacteria Escherichia coli and Acinetobacter baumannii is $2.5 \mu \mathrm{L} / \mathrm{mL}$. These strains are considered to be the most sensitive by comparison with the other bacteria studied.

The low antimicrobial activity of the essential oil can be explained by its low chemical profile in compounds known for their antimicrobial power, such as certain oxygenated monoterpenes $[25,26]$.

Our results are in agreement with those obtained by Bourkhiss et al. [15] who tested the same essential oil in vitro against four bacterial and two fungal strains, and only Staphylococcus aureus and Micrococcus luteus were found sensitive.

The $\mathrm{MBC} / \mathrm{MIC}$ ratio defines the bacteriostatic or bactericidal character of an essential oil; if this ratio is less than 4, then the oil is considered bactericidal [27].

The MBC/MIC ratio of the essential oil of Thuya branches is between 1 and 2, which confirms that the oil exerts a bactericidal effect (Table 4).

\section{Conclusions}

In the present work, we studied the chemical composition and the in vitro antibacterial activity of the essential oil of the branches of Tetraclinis articulata (Vahl) Masters of the Eastern Morocco against pathogenic strains of clinical origin. The extraction of the branches by hydrodistillation results in a yield of $0.84 \pm 0.01 \%$. For the determination of chemical composition, the essential oil was analysed by gas chromatography coupled with mass spectroscopy. The results show that this oil contains mostly $\alpha$-pinene (38.75\%), limonene (13.24\%), 
Table 4 Antibacterial parameters (MIC and MBC) of the essential oil of the Tetraclinis articulata and their interpretation

\begin{tabular}{|c|c|c|c|c|}
\hline Bacterial strains & MIC $(\mu L / m L)$ & $M B C(\mu L / m L)$ & MBC/MIC & Interpretation \\
\hline Escherichia coli & 2.5 & 2.5 & 1 & Bactericidal \\
\hline Klebsiella pneumoniae & 80 & 80 & 1 & Bactericidal \\
\hline Acinetobacter baumannii & 2.5 & 5 & 2 & Bactericidal \\
\hline Staphylococcus aureus & 40 & 80 & 2 & Bactericidal \\
\hline
\end{tabular}

bornyl acetate $(8.78 \%)$ and camphor $(7.68 \%)$. The study of in vitro inhibitor power shows that the essential oil tested has significant antibacterial activity against Escherichia coli and Acinetobacter baumannii, two strains that are resistant. Generally, the results obtained are promising and open new perspectives in the field of natural applications which can be a viable alternative to synthetic products.

\section{Abbreviations}

MIC: minimum inhibitory concentration; MBC: minimum bactericidal concentration; ESBL: extended-spectrum beta-lactamases.

\section{Author's contributions}

Not applicable.

\begin{abstract}
Author details
${ }^{1}$ Laboratory of Molecular Chemistry and Natural Substances, Department of Chemistry, Faculty of Sciences of Meknes, Moulay Ismail University, Bp 11201, Zitoune, Meknes, Morocco. ${ }^{2}$ Laboratory of Microbiology, Military Hospital Moulay Ismail, Meknes, Morocco. ${ }^{3}$ Laboratory of Plant Biotechnology and Molecular Biology, Faculty of Science, Moulay Ismail University, BP 11201 Zitoune Meknes, Morocco. ${ }^{4}$ Department of Pharmacognosy, Faculty of Pharmacy, University of Medicine and Pharmacy, "Gr. T. Popa", lasi, Str. 16University Str., lasi 700115, Romania. ${ }^{5}$ Department of Biology, Faculty of Biology, Alexandru loan Cuza University of lasi, Bv Carol I, No 11, 700505 lasi, Romania.
\end{abstract}

\section{Acknowledgements}

Not applicable.

\section{Competing interests}

The authors declare that they have no competing interests.

\section{Availability of data materials}

Not applicable.

Ethics approval and consent to participate

Not applicable.

\section{Funding}

Not applicable.

\section{Publisher's Note}

Springer Nature remains neutral with regard to jurisdictional claims in published maps and institutional affiliations.

Received: 14 August 2018 Accepted: 1 November 2018 Published online: 17 December 2018

\section{References}

1. Stanier RY, Doudoroff M, Adelberg Ed A. Microbiologie générale. Masson et Cie Editeurs; 1996.
2. Berche P, Gaillard JL, Simone M. Bactériologie: bactéries des infections humaines. Val-de-Meuse: Flammarion Médecine-Sciences; 1989.

3. Djeussi DE, Noumedem JAK, Seukep JA, Fankam AG, Voukeng IK, Tankeo SB, Nkuete AHL, Kuete V. Antibacterial activities of selected edible plants extracts against multidrug-resistant Gram-negative bacteria. BMC Complement Altern Med. 2013. https://doi.org/10.1186/1472-6882-13-164.

4. Djabou N, Lorenzi V, Guinoiseau E, Andreani S, Giuliani MC, Desjobert JM, Bolla JM, Costa J, Berti L, Luciani A, Muselli A. Phytochemical composition of Corsican Teucrium essential oils and antibacterial activity against foodborne or toxi-infectious pathogens. Food Control. 2013. https://doi.org/10.1016/j. foodcont.2012.06.025.

5. Andrade BFTM, Barbosa LN, Probst IS, Júnior AF. Antimicrobial activity of essential oils. J Essent Oil Res. 2014. https://doi.org/10.1080/10412 905.2013.860409.

6. Chekol YA, Desta ZY. Determination of antioxidant and antimicrobial activities of leaf extracts of Otostegia integrifolia. Chem Cent J. 2018. https://doi. org/10.1186/s13065-018-0433-2.

7. Pombal S, Rodrigues CF, Araújo JP, Rocha PM, Rodilla JM, Diez D, Granja AP, Gomes AC, Silva LA. Antibacterial and antioxidant activity of Portuguese Lavandula luisieri (Rozeira) Rivas-Martinez and its relation with their chemical composition. SpringerPlus. 2016. https://doi.org/10.1186/s4006 4-016-3415-7.

8. Dimitrova L, Zaharieva MM, Popova M, Kostadinova N, Tsvetkova I, Bankova $\checkmark$, Najdenski H. Antimicrobial and antioxidant potential of different solvent extracts of the medicinal plant Geum urbanum L. Chem Cent J. 2017. https ://doi.org/10.1186/s13065-017-0343-8.

9. Islam MZ, Hossain MT, Paul SC, Hossen F, Mukharjee SK, Sultana N. Evaluation of antioxidant and antibacterial activities of Crotalaria pallida stem extract. Clin Phytosci. 2018;1:1. https://doi.org/10.1186/s40816-018-0066-y.

10. Fournomiti M, Kimbaris A, Mantzourani I, Plessas S, Theodoridou I, Papaemmanouil V, Kapsiotis I, Panopoulou M, Stavropoulou E, Bezirtzoglou EE, Alexopoulos A. Antibacterial activity of essential oils of cultivated oregano (Origanum vulgare), sage (Salvia officinalis), and thyme (Thymus vulgaris) against clinical isolates of Escherichia coli, Klebsiella oxytoca, and Klebsiella pneumonia. Microb Ecol Health Dis. 2015. https://doi.org/10.3402/mehd. v26.23289.

11. Asghar N, Naqvi SAR, Hussain Z, Rasool N, Khan ZA, Shahzad SA, Sherazi TA, Janjua MRSA, Nagra SA, Zia-UI-Haq M, Jaafar HZ. Compositional difference in antioxidant and antibacterial activity of all parts of the Carica papaya using different solvents. Chem Cent J. 2016. https://doi.org/10.1186/s1306 5-016-0149-0.

12. Dakak JE. Relation entre la qualité du bois de thuya de Maghreb (Tetraclinis articulata) et ses conditions de développement sur ses principaux sites phytoécologiques de son bloc méridional au Maroc. Nancy: Ecole Nationale du Génie Rural, des Eaux et des Forêts (ENGREEF); 2002.

13. Belkhadar J, Claisse R, Fleurentin J, Younos C. Repertory of standard herbal drugs in the Moroccan pharmacopoeia. J Ethnopharmacol. 1999;35:123-43.

14. Clevenger JF. Apparatus for the determination of volatile oil. J Am Pharm Assoc. 1928;1:1. https://doi.org/10.1002/jps.3080170407.

15. Bourkhiss B, Ouhssine M, Hnach M, Bourkhiss M, Strani B, Farah A. Composition chimique et bioactivité de l'huile essentielle des rameaux de Tetraclinis Articulata. Bull Soc Pharm Bordeaux. 2007;146:75-84.

16. Buhagiar J, Podestà MTC, Cioni PL. Essential oil composition of different parts of Tetraclinis articulata. Int J Herb Med. 2000. https://doi. org/10.1080/10412905.2000.9712034

17. Ait Igri M, Holeman M, llidrissi A, Berrada M. Contribution à l'étude des huiles essentielles des rameaux et de bois de Tetraclinis articulata (Vahl) Masters. Plant Med Phytother. 1990;24:36-43. 
18. Tékaya-Karoui A, Ben Jannet H, Mighri Z. Essential oil composition of terminal branches, cones and roots of Tetraclinis articulata from Tunisia. Pak J Biol Sci. 2007;10:2495-9.

19. Bertini LM, Pereira AF, Oliveira CLL, Menezes EA, Morais SM, Cunha FA, Cavalcanti ESB. Perfi de sensibilidade de bactérias frente a óleos essenciais de algumas plantas do nordeste do Brasil. Infarma. 2005;17:80-3.

20. Gende LB, Mendiara S, Fernández NJ, Baren CV, Lira LA, Bandoni A, Fritz R, Floris I, Eguaras M. Essentials oils of some Mentha spp. and their relation with antimicrobial activity against Paenibacillus larvae, the causative agent of American foulbrood in honey bees, by using the bioautography technique. Bull Insect. 2014;67:13-20.

21. Colombo RP, Martíneza AE, Pardo AF, Bidondo LF, Baren VC, Lira LP, Godeas AM. Differential effects of two strains of Rhizophagus intraradices on dry biomass and essential oil yield and composition in Calamintha nepta. Rev Argent Microbiol. 2013;45:114-8.

22. Kapoor R, Giri B, Mukerji KG. Glomus macrocarpum: a potential bioinoculant to improve essential oil quality and concentration in Dill (Anethum graveolens L.) and Carum [Trachyspermun ammi (Linn.) Sprague]. World J Microbiol Biotechnol. 2002;1:1. https://doi.org/10.1023/a:1015522100497.
23. Baydar H, Sagdic O, Ozkan G, Karadogan T. Antibacterial activity and composition of essential oils from Origanum, Thymbra and Satureja species with commercial importance in Turkey. Food Control. 2004. https://doi. org/10.1016/S0956-7135(03)00028-8.

24. Koba K, Sanda K, Raynaud C, Nenonene YA, Millet J, Chaumont JP. Activités antimicrobiennes d'huiles essentielles de trois Cymbopogon sp. africains vis-à-vis de germes pathogènes d'animaux de compagnie. Ann Méd Vét. 2004;148:202-6

25. Dorman HJD, Deans SG. Antimicrobial agents from plants: antibacterial activity of plant volatile oils. J Appl Microbiol. 2000;88:308-16.

26. Oussalah M, Caillet S, Saucier L, Lacroix M. Inhibitory effects of selected plant essential oil on the growth of four pathologic bacteria: E. coli O157: H7, Salmonella typhimurium, Staphylococcus aureus and Listeria monocytogenes. Food Control. 2007. https://doi.org/10.1016/j.foodcont.2005.11.009.

27. Guinoiseau E. Molécules antibactériennes issues d'huiles essentielles: séparation, identification et mode d'action. PhD thesis. Corse: University of Corse; 2011.

\section{Submit your manuscript to a SpringerOpen ${ }^{\circ}$ journal and benefit from:}

- Convenient online submission

- Rigorous peer review

- Open access: articles freely available online

- High visibility within the field

- Retaining the copyright to your article

Submit your next manuscript at $\gg$ springeropen.com 